DOI: $10.32347 / 2412-9933.2020 .41 .147-155$

УДК 005.8

\title{
Чжоу Хуань
}

Аспірант кафедри інформаційних систем і технологій, orcid.org/0000-0003-1187-8161

Київський національний університет імені Тараса Шевченка, Київ

\section{ГАРМОНІЗАЦІЯ КИТАЙСЬКОЇ МІЖНАРОДНОЇ СИСТЕМИ СЕРВІСУ ДЛЯ СТУДЕНТІВ}

\begin{abstract}
Анотація. Сучасне ПЗ полегшує управління людськими ресурсами на малих, середніх та великих підприсмствах технічного, інформаційного, фінансового й інших напрямів. Але питання інтегрованих програмних продуктів для закладів освіти досі залитається відкритим.

Розвиток китайської міжнародної системи сервісу для студентів відбувається стало, проте на думку автора недостатньо стрімко. Для глобалізаиії процесу навчання іноземних студентів доиільно використовувати інтегровану навчальну платформу. Для такої платформи розроблено низку навчальних курсів. Гармонізачія китайської міжнародної системи сервісу для студентів та інтегрованої навчальної платформи дасть можливість підвищити рівень управління людськими ресурсами для закладів навчання.
\end{abstract}

Ключові слова: гармонізація навчальних платформ; міжннародна система сервісу для студентів; інтегрована навчальна платформа

\section{Аналіз останніх досліджень і публікацій}

Важливість управління людськими ресурсами (HRM) в організаціях не викликає сумнівів. Широко відома необхідність узгодження HRM та стратегій бізнесу [1]. Ефективне HRM життєво необхідне для того, щоб відповідати вимогам ринку, які постійно змінюються [2].

Технології та HRM мають широкий спектр впливів один на одного, i HR фахівці повинні мати можливість впроваджувати технології, що дозволяють реінжиніризувати функцію управління персоналом, бути готовими підтримувати організаційні зміни та зміни в роботі, що виникають внаслідок розвитку технологій, а також мати змогу підтримувати належний управлінський клімат для інноваційних та наукоємних організацій [3]. Технологічні досягнення просуваються насамперед завдяки високим вимогам професіоналів з людських ресурсів для підвищення швидкості, ефективності та зниження витрат [4].

Дослідження Снела, Штуйбера та Лепака [5] засвідчили, що завдяки використанню інформаційних технологій системи управління людськими ресурсами можуть вирішувати завдання більш стратегічно, гнучко, економічно ефективно і більш орієнтовано на клієнта. Багато експертів прогнозують, що ПК стане центральним інструментом для всіх фахівців у сфері HR [6]. Віртуалізація управління людськими ресурсами викликана фактором зростаючої складності інформаційних технологій та збільшенням зовнішніх структурних параметрів [7]. Інформаційні технології дають можливість для організацій здійснювати відповідні до сьогодення операції 3 управління людськими ресурсами. А широкий спектр пропозицій на ринку технологій управління людськими ресурсами дає змогу використовувати найсучасніші системи при мінімальному інвестуванні [8].

Одним 3 наслідків широкого розповсюдження інформаційних технологій $є$ створення робочого місця, що базується на IT [9]. Це своєю чергою сприяє головному пріоритету менеджера, а саме стратегічному управлінню компетенціями [10]. Розвиток інформаційних технологій дає можливість здійснювати велику кількість завдань HRM, наприклад, залучення, утримання та мотивування працівників, задоволення вимог до більш стратегічних функцій управління персоналом, а також управління "людським елементом" технологічних змін у майбутньому [11]. Управління персоналом може підтримувати зусилля технологічних інновацій для досягнення високої продуктивності. Отже, сам по собі може служити підходом для того, щоб функція управління персоналом могла більше зосередитися на діяльності 3 доданою вартістю 3 метою реалізації повного потенціалу технологічної та організаційної стратегії [12]. Найбільша вигода від використання IT в HRM для організацій - це позбавлення HR-персоналу посередницькі ролі, що допомагає йому зосередитися на стратегічному плануванні в організації та розвитку людських ресурсів [13]. Кадрон [14] також зауважив, що IT може автоматизувати інші рутинні завдання, такі як опрацювання заробітної плати, адміністрування пільг і транзакційні заходи так, що 
фахівці з персоналу можуть вільно фокусуватися на більш стратегічні питання, такі як підвищення продуктивності.

Сучасний стан систем управління людськими ресурсами

Система управління людськими ресурсами (HRMS) - це програмне забезпечення для роботи 3 базами даних та прикладних програм для здійснення кадрових операцій службовців через Інтернет. Програмне забезпечення HRMS автоматично готує всі рахунки та реєстри працівника, такі як сервісна книга, обліковий запис відпустки, рахунок кредиту, обліковий запис заробітної плати, діаграма посадових осіб тощо, отримуючи відповідні дані 3 операцій. Вона також допомагає працівникам, що працюють у пенсійному фонді, підготувати пенсійні папери за допомогою кнопок і допомогти владі легко i швидко опрацювати пенсійні папери. Минулі транзакції фіксуються, як застарілі дані та включаються до бази даних, а наступні транзакції записуються в реальному часі. Службова книга кожного співробітника $\epsilon$ найбільш повним репозитарієм таких операцій. Таким чином, сервісні дані кожного співробітника із сервісної книги є основою бази даних HRMS.

П'ять інструментів соиіального управління людськими ресурсами для спрощення спільних проєктів [15]

HRMS часто розглядається робочою силою як корисне лише для розрахунку заробітної плати, розслідування часу та інших специфічних завдань, пов'язаних $з$ персоналом. Правда полягає в тому, що деякі з останніх соціальних особливостей привносять людські ресурси в повсякденне життя людей, а не лише як доповнення, але як інструмент, який потенційно може трансформувати співпрацю людей. A саме:

1. Соціальне планування

Такі функції, як групові календарі, можуть використовуватися проєктними групами для перегляду та організації часу один одного, а отже, підвищення продуктивності - особливо цінні при роботі 3 міждисциплінарними командами проєктів, доступ до яких може бути обмежений у традиційному програмному забезпеченні планування. Додайте до цього функції, такі як дискусійні групи (відкриті та закриті), керування завданнями та навіть «соціальні інформаційні панелі», соціальні системи управління людськими ресурсами можуть забезпечити свіжий рівень видимості та прозорості для роботи проєкту.

\section{2. Обмін знаннями}

Якщо одне слово підсумовує соціальні медіа, це, мабуть, «поділиться» - настільки, що це може стати кліше. Внутрішні соціальні мережі дають змогу командам проєктів організації обмінюватися думками, знаннями, висновками та керувати ресурсами та темами обговорення, пов'язаними 3 ключовими цілями та проєктними діями. Крім того, команда проєкту може також проводити поточні запитання щодо проєктів, залучаючи ширшу інформацію, що виходить за рамки обмежень традиційних організаційних силосів.

\section{3. Навчання}

Традиційним джерелом нових знань і навичок був відділ підготовки компанії. Але хоча це джерело може бути настільки ж багатим, як і раніше, соціальні інструменти дозволяють кожному в організації бути джерелом навчання. Це може бути просто онлайндискусійна група або форум чату, або це може бути спільною практикою, що розвивається, пов'язаною 3 цілями проєкту.

\section{4. Нагорода і визнання}

Бути поміченим за добру роботу має стати неймовірною мотиваційною силою. Старі корпоративні ієрархії мають тенденцію обмежувати зворотний зв'язок, визнання та винагороди в межах ланцюга управління. Деякі соціальні пакети HRMS надають можливість будь-кому визнати добрі зусилля (і результати) будь-кого в межах команди проєкту; навіть рекомендувати їх для відчутної винагороди. А за допомогою мобільних технологій ця комбінація розпізнавання однолітків та управління продуктивністю в режимі реального часу доступна колегам, розкиданим по всьому світу.

\section{5. Непроєктні виклики}

Не всі команди та співпраця пов'язані 3 проєктами. Насправді команди, які працюють або грають разом за межами проєктного завдання, як правило, працюють краще в цілому.

Інструменти соціальної системи управління людськими ресурсами можна використовувати для організації та управління командними викликами та заходами, орієнтованими на людей, а не орієнтованими на проєкти. Наприклад, виклик оздоровчого характеру - використовуючи функції гейміфікації, такі як точки, рівні та значки, - вказує на внутрішньокомандні конкурентні імпульси, щоб мотивувати здоровий спосіб життя, що приводить до формування більш сприятливої команди.

\section{Викладення основного матеріалу}

Основні програмні продукти для систем управління людськими ресурсами

\section{High Line}

High Line [16] - це інтегрована система управління людськими ресурсами, розроблена для компаній зі складними бізнес-вимогами. Вона має модульну конструкцію, що означає, що компанії можуть купувати тільки ті компоненти, які їм потрібні.

High Line пропонує рішення у таких основних функціональних сферах: людські ресурси, нарахування заробітної плати, хронометраж та управління талантами. 
Однією з головних переваг High Line є те, що він може налаштувати свої рішення на основі унікальних вимог компанії. Компанії мають можливість додавати інші модулі в будь-який момент, оскільки їх потреби зростають.

Інші переваги використання High Line:

- уніфікована платформа HRMS, що виключає необхідність роботи з професіоналами HR з різними системами;

- зручний інтерфейс 3 функціональністю самообслуговування для кінцевих користувачів;

- автоматизовані бізнес-процеси підвищення ефективності та продуктивності.

На додаток до чотирьох модулів (рис. 1, 2) High Line пропонує інші рішення, такі як безпека та охорона здоров'я, профспілкові та трудові відносини, бухгалтерський облік грантів та пенсійне управління. Вона також пропонує інтегрований інструмент бізнес-аналітики, який допомагає HR та менеджерам виявляти тенденції та проблеми в даних про своїх співробітників.

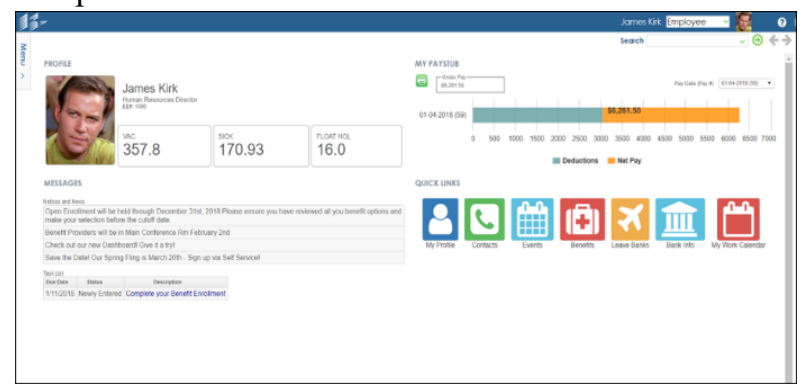

Рисунок 1 - Скріншот персональної сторінки співробітника в програмному забезпеченні High Line
Ось деякі 3 ключових особливостей кожного модуля High Line:

Людські ресурси - модуль «Людські ресурси» включає деякі з цих функцій:

- організаційні схеми;

- адміністрування переваг, таких як автоматизована відкрита реєстрація та події життя;

- функціональність самообслуговування;

- управління ефективністю, наприклад, оцінки ефективності, огляд заробітної плати та відстеження компетентності;

- можливість відстежувати онлайн-навчання, включаючи запити та схвалення;

- автоматизовані процеси робочого процесу, включаючи маршрутизацію відповідних осіб;

- сповіщення та сповіщення про певні події.

Розрахунок заробітної плати - деякі з функцій, включених до модуля нарахування заробітної плати:

- збирання часових даних 3 модуля хронометражу та третіх систем обліку часу;

- можливість працювати 3 працівниками, підрядниками та постачальниками;

- гнучка частота оплати та необмежені правила оплати;

- федеральні, державні та місцеві податкові відрахування та звітність за підсумками року;

- інтеграція в головні книги, кредиторську заборгованість та інші фінансові системи;

- прямий депозит.

Розрахунок заробітної плати здійснюється партнером High Line для тих компаній, які хочуть аутсорсингу заробітної плати.

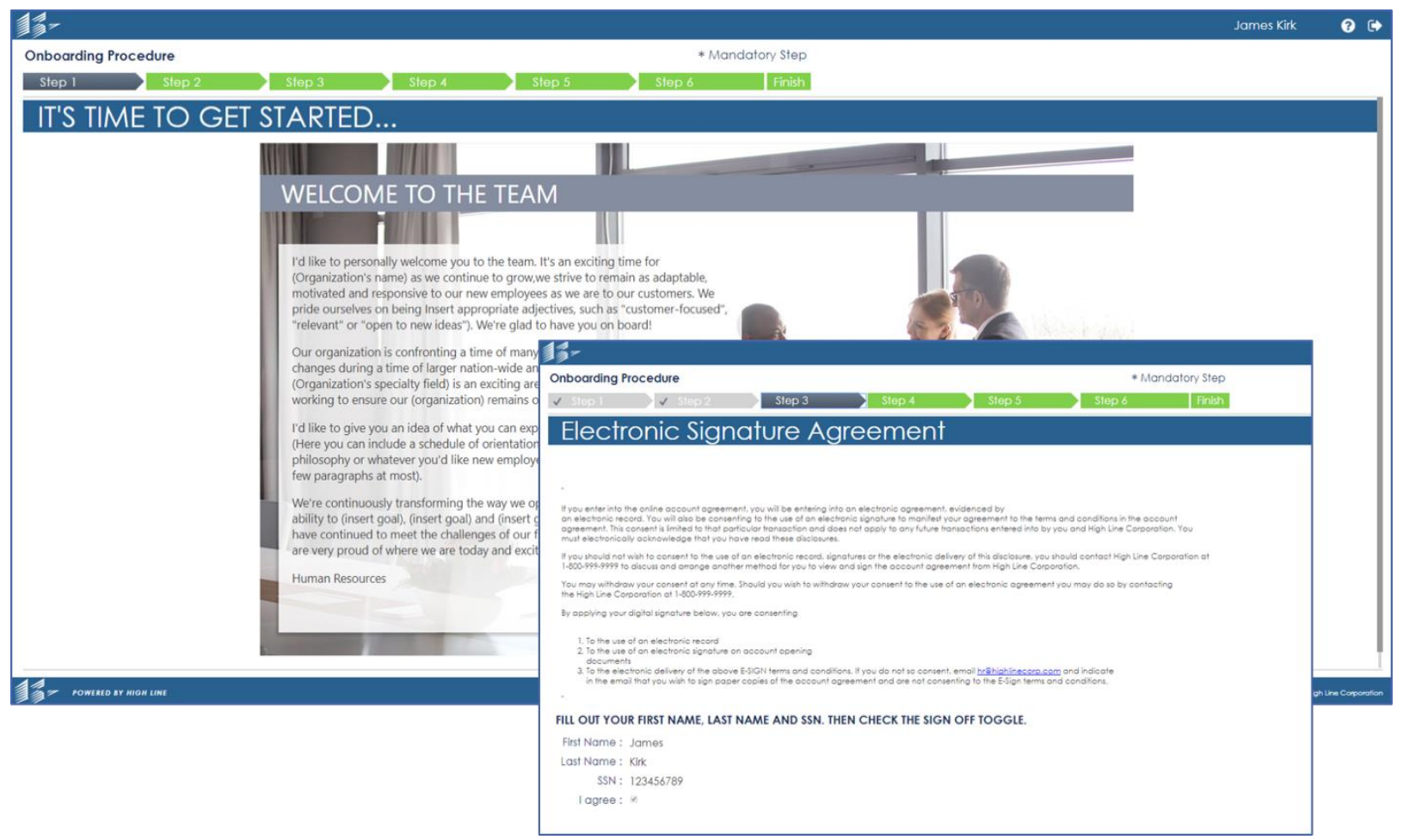

Рисунок 2 - Скріншот сторінки High Line 
Хронометраж - деякі 3 функцій модуля

Timekeeping включають таке:

- співробітники проводять розкладу часу

самостійного обслуговування і залишають запити;

- настроювані листи часу;

- інтеграція до існуючих часових годинників;

- вбудовані годинники вебчасу;

- автоматизовані складні правила обліку часу, включаючи правила профспілкового контракту;

- автоматизоване планування зміни.

Управління талантами та придбання - модуль "Набуття талантів" включає кілька функцій підбору персоналу, таких як:

- процес автоматизованої роботи;

- шаблони опису завдань;

- онлайн-програми та оцінки;

- відновити розбір;

- портал правління;

- функціональність

самообслуговування кандидата;

- виділений портал для працевлаштування менеджерів для перегляду профілю кандидата та надання зворотного зв'язку;

- завдання та контрольні списки;

- кнопка "Оренда", яка автоматично створюе новий запис співробітника для модуля "Людський ресурс" (але все ще зберігає всі дані щодо рекрутингу, пов'язані з профілем-кандидатом).

High Line пропонує розгортання на основі хмарних обчислень. Вона також надає клієнтам послуги 3 впровадження та консалтингу. Незважаючи на те, що вони мають структуровану стратегію впровадження, конкретні компоненти та терміни залежать від конкретних вимог клієнта.

Додаткові послуги High Line передбачають планування проєктів, навчання адміністраторів i кінцевих користувачів, а також налаштування інтерфейсу користувача.

\section{Kronos Workforce Ready}

Kronos Workforce Ready Suite [17] складається 3 різних модулів, які допомагають компаніям керувати своїми робочими силами від попереднього найму до наступного. Цей огляд буде зосереджено на своєму модулі HR Human Ready.

Kronos Workforce Ready HR - це рішення 3 управління людським капіталом (НСM), розроблене для компаній з погодинними та / або найманими працівниками. Місія цього рішення полягає в тому, щоб HR зосередився на людях, а не на документах (рис. 3 , 4). Вона включає кілька переваг, таких як:

- більш автоматизовані HR процеси, завдяки чому підвищиться продуктивність HR менеджерів;

- функції самообслуговування для працівників та їх керівників;

- розгортання в хмарі з доступом до Інтернету та мобільних пристроїв;
- більш стратегічна увага приділяється працівникам $з$ додатковим управлінням талантами, управлінням продуктивністю та модулями управління компенсаціями.

Ось декілька основних функцій, які включені в службу готовності робочої сили:

- всі записи співробітників зберігаються в єдиній базі даних;

- функціональні можливості самообслуговування співробітників для оновлення власної інформації без участі персоналу;

- можливість налаштування процесів для виконання HR завдань, таких як нові співробітники, припинення, зміни роботи та зміни заробітної плати;

- індивідуальні контрольні списки на борту 3 автоматизованими нагадуваннями;

- можливість керувати декількома планами вигід (медичне страхування або пенсійні пакети) в одному рішенні;

- управління розвитком навчання працівників, включаючи присвоєння їм конкретних класів, моніторинг участі в тренінгах $\mathrm{i}$ завершення та планування внутрішнього навчання.

Kronos пропонує стратегічні функції HR з цими додатковими модулями.

По-перше, існує модуль підготовки талантів робочої сили для відстеження та рекрутингу заявників. Рекрутери можуть створювати оголошення про вакансії, вибирати кандидатів 3 багатьох баз і управляти робочими процесами. Коли наймається кандидат, інформація 3 його резюме та додатків передається в модуль HR.

По-друге, існує модуль управління продуктивністю робочої сили, який постійно підтримує відгуки про працездатність працівників. Вона включає в себе функції, такі як індивідуальні огляди продуктивності, визначення цілей працівників і підрозділів, а також попередження про статус розкладу перевірки працездатності працівників.

I, нарешті, є додатковий модуль управління робочою силою готової компенсації. Він замінює електронні таблиці в управлінні циклом компенсації шляхом автоматизації всього процесу. Процес компенсації може бути налаштований на основі потреб та бюджетів підприємства. Існує також функція Матриця заслуг, яка допомагає встановити керівні принципи щодо підвищення заробітної плати на основі заслуг.

Kronos пропонує своє програмне забезпечення через хмарну модель для повного доступу до оновлень і синхронізації.

Процес імплементації має шість етапів:

- планування;

- оцінювання;

- прийняття рішення; 
- тестування і тренування;

- початок роботи;

- перехід на підтримку.

Процес починається 3 визначення очікувань клієнтів від програмного забезпечення, i він просувається вперед, оцінюючи дані про співробітників. Потім додається та відформатовується інформація про працівників та історію нарахування заробітної плати в системі. Після завершення тестування програмне забезпечення готове для щоденного використання.

Сучасне ПЗ полегшує управління людськими ресурсами на малих, середніх та великих підприємствах технічного, інформаційного, фінансового та інших напрямів. Але питання інтегрованих програмних продуктів для закладів освіти досі залишається відкритим [18].

Розвиток китайської міжнародної системи сервісу для студентів відбувається стало, проте на думку автора, недостатньо стрімко. Для прикладу представлено програму, в якій зараз ведеться зарахування іноземних студентів в один із університетів провінції Шандунь (рис. 5 - 8).

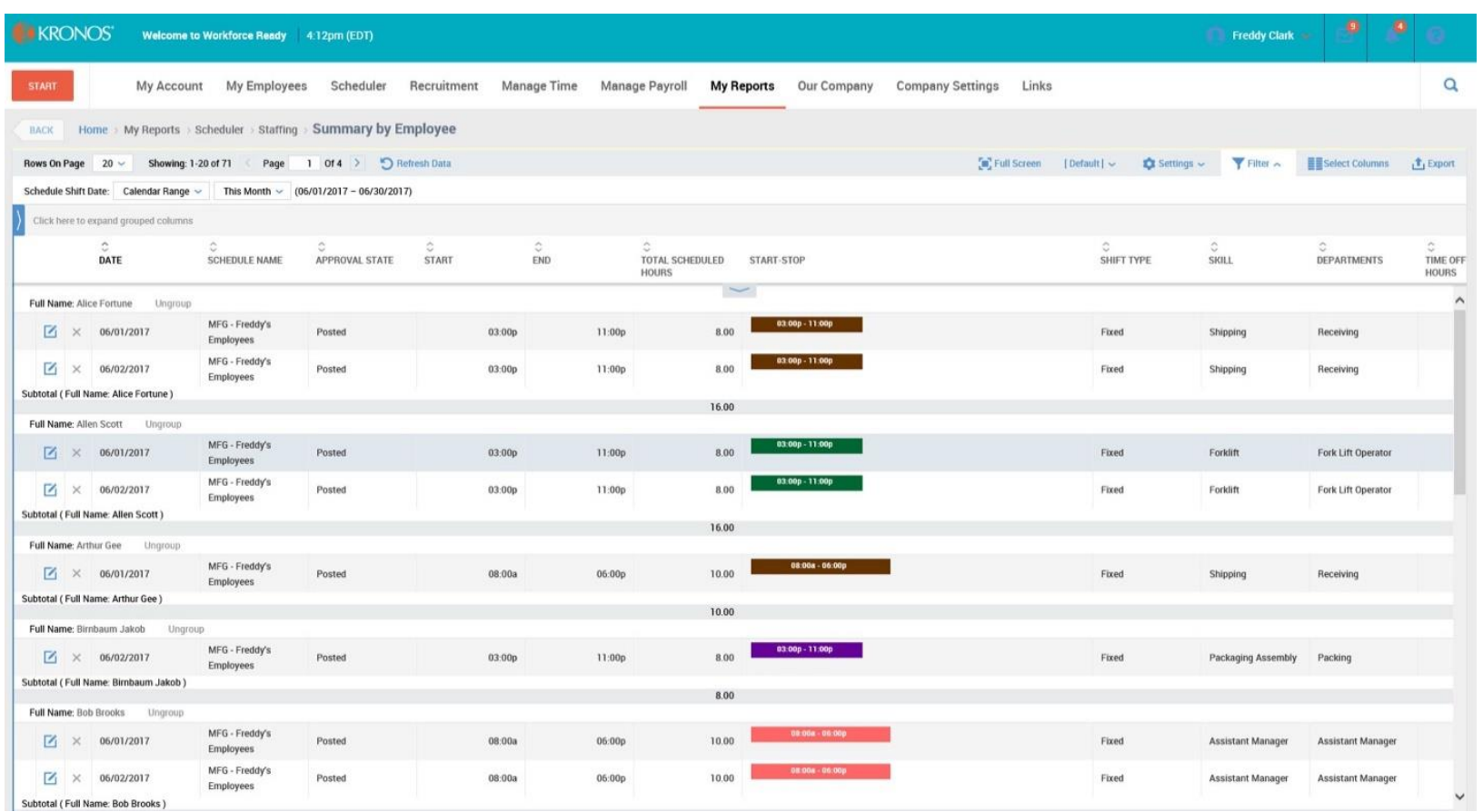

Рисунок 3 - Скріншот обліку роботи співробітників в Kronos Workforce

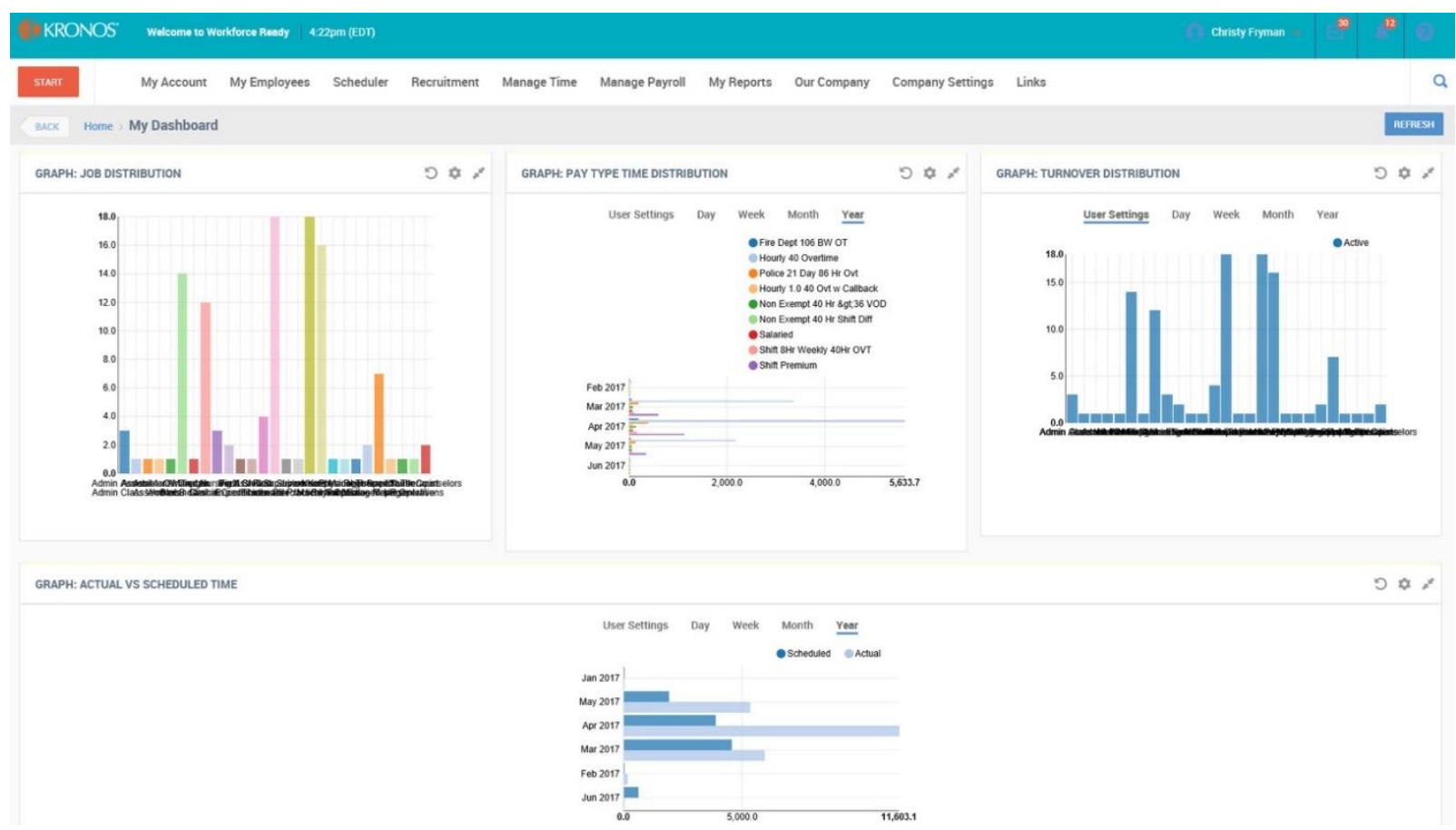

Рисунок 4-Скріншот сторінки dashboard в Kronos Workforce 


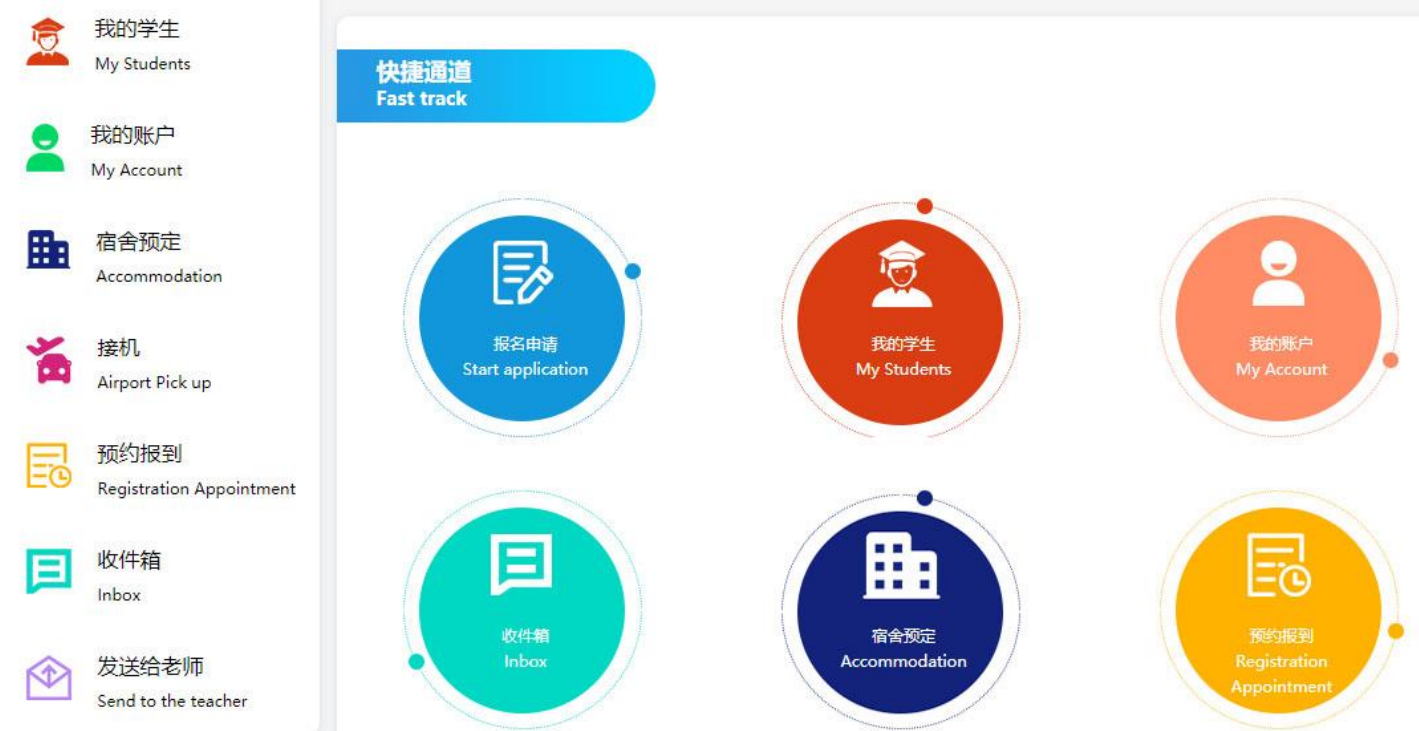

Рисунок 5 - Скріншот головного меню міжнародної системи сервісу для студентів

My applications

\section{在线申清}

Start application

$\widehat{\text { 首页 }}$

圧报名申请

-C Start application

B) 我的学生

My Students

○ 我的账户

My Account

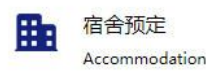

接机

Taught by: All language $\quad$ Program: Program

\begin{tabular}{|c|c|c|c|c|c|c|c|c|}
\hline $\begin{array}{c}\text { 院系 } \\
\text { College }\end{array}$ & $\begin{array}{l}\text { 学生㫧别 } \\
\text { Degree }\end{array}$ & $\begin{array}{l}\text { 学习专业 } \\
\text { Program }\end{array}$ & $\begin{array}{c}\text { 专业学历 } \\
\text { Program Deg } \\
\text { ree }\end{array}$ & $\begin{array}{c}\text { 授课语 } \\
\text { 言 } \\
\text { Taught } \\
\text { by }\end{array}$ & $\begin{array}{l}\text { 学亚 } \\
\text { Tution } \\
\text { fee }\end{array}$ & $\begin{array}{l}\text { 学制 } \\
\text { Years }\end{array}$ & $\begin{array}{l}\text { 报各截止 } \\
\text { Apply deadli } \\
\text { ne }\end{array}$ & $\begin{array}{c}\text { 鼣作 } \\
\text { Opation }\end{array}$ \\
\hline $\begin{array}{l}\text { 数学与系统科学学院 } \\
\text { College of Mathematics } \\
\text { and Systems Science }\end{array}$ & $\begin{array}{l}\text { 博士研究生 } \\
\text { Doctoral } \\
\text { degree }\end{array}$ & $\begin{array}{l}\text { 系统科学 } \\
\text { System Science }\end{array}$ & $\begin{array}{l}\text { 博士研究生 } \\
\text { Doctoral } \\
\text { degree }\end{array}$ & $\begin{array}{l}\text { 中文 } \\
\text { Chines } \\
\text { e }\end{array}$ & 26000 & $4 \mathrm{Y}$ & & 由请 / Apply \\
\hline $\begin{array}{l}\text { 数学与系统科学学院 } \\
\text { College of Mathematics } \\
\text { and Systems Science }\end{array}$ & $\begin{array}{l}\text { 㙛士研究生 } \\
\text { Doctoral } \\
\text { degree }\end{array}$ & $\begin{array}{l}\text { 系统科学 } \\
\text { yystem Science }\end{array}$ & $\begin{array}{l}\text { 埥土研究生 } \\
\text { Doctoral } \\
\text { degree }\end{array}$ & $\begin{array}{l}\text { 英文 } \\
\text { English }\end{array}$ & 26000 & $4 Y$ & & 由清 / Apply \\
\hline $\begin{array}{l}\text { 数学与系统科学学院 } \\
\text { College of Mathematics } \\
\text { and Systems Science }\end{array}$ & $\begin{array}{l}\text { 博士研究生 } \\
\text { Doctoral } \\
\text { degree }\end{array}$ & $\begin{array}{l}\text { 系统科学 } \\
\text { system science }\end{array}$ & $\begin{array}{l}\text { 博士研究生 } \\
\text { Doctoral } \\
\text { degree }\end{array}$ & $\begin{array}{l}\text { 中英文 } \\
\text { English } \\
\& \\
\text { Chines } \\
\text { e }\end{array}$ & 26000 & 4年 & & 由清 / Apply \\
\hline $\begin{array}{l}\text { 机根电子工程学院 } \\
\text { College of Mechanical } \\
\text { and Electronic } \\
\text { Engineering }\end{array}$ & $\begin{array}{l}\text { 博士研究生 } \\
\text { Doctoral } \\
\text { degree }\end{array}$ & 矿山机电技术与特备 & $\begin{array}{l}\text { 䏆士研究生 } \\
\text { Doctoral } \\
\text { degree }\end{array}$ & & 26000 & $4 \mathrm{~V}$ & & 由请 / Apply \\
\hline $\begin{array}{l}\text { 地球科学与工程学院 } \\
\text { College of Earth Science } \\
\text { and Engineering }\end{array}$ & $\begin{array}{l}\text { 博士研究生 } \\
\text { Doctoral } \\
\text { degree }\end{array}$ & $\begin{array}{l}\text { 太资源与环境保护 } \\
\text { Resource \& } \\
\text { Protection Environment }\end{array}$ & $\begin{array}{l}\text { 博士研究生 } \\
\text { Doctoral } \\
\text { degree }\end{array}$ & $\begin{array}{l}\text { 中文 } \\
\text { Chines } \\
\text { e }\end{array}$ & 26000 & $4 \mathrm{~V}$ & & 由清 / Apply \\
\hline
\end{tabular}

Рисунок 6-Скріншот меню вибору спеціальностей міжнародної системи сервісу для студентів

$\widehat{\text { 首页 }}$

报名申请

Start application

申请项目 / Course: Control Theory \& Control Engineering / 质制䧉论与控制工程

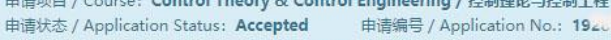

央遂公司/ Express Company: 快道单号 / Tracking number:

我的学生

个人甚本信息 Personal Information

My Students

护殿娃 Passport Family Name

莪的账户

My Account

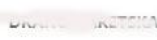

护照名 Given Name

明宿舍预定

ㄷ․….......

Accommodation

中文名 Chinese Name

Browser...

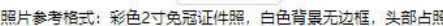

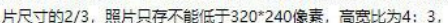
大小为100-500KB, JPG 模式 (".jpg,".jpeg, .ppng).

Reference:JPG Color 2"Bareheaded Certificate White

接机 珄别 Sex*

\begin{tabular}{l|l} 
Airport Pick up & Female
\end{tabular}

预约报到国篗 Nationality

Registration Appointment

乌克兰Ukraine

出生曰期 Date of Birth" Background Without Border) The head is $2 / 3$ of the size of
the photograph, the photo size is not less than $320 \times 240$ pixels, the aspect ratio is $4: 3$, the size is $100-500 \mathrm{~kb}$ ).

末婚 / Single

Рисунок 7 - Скріншот персональної анкети студента в міжнародній системі сервісу для студентів 


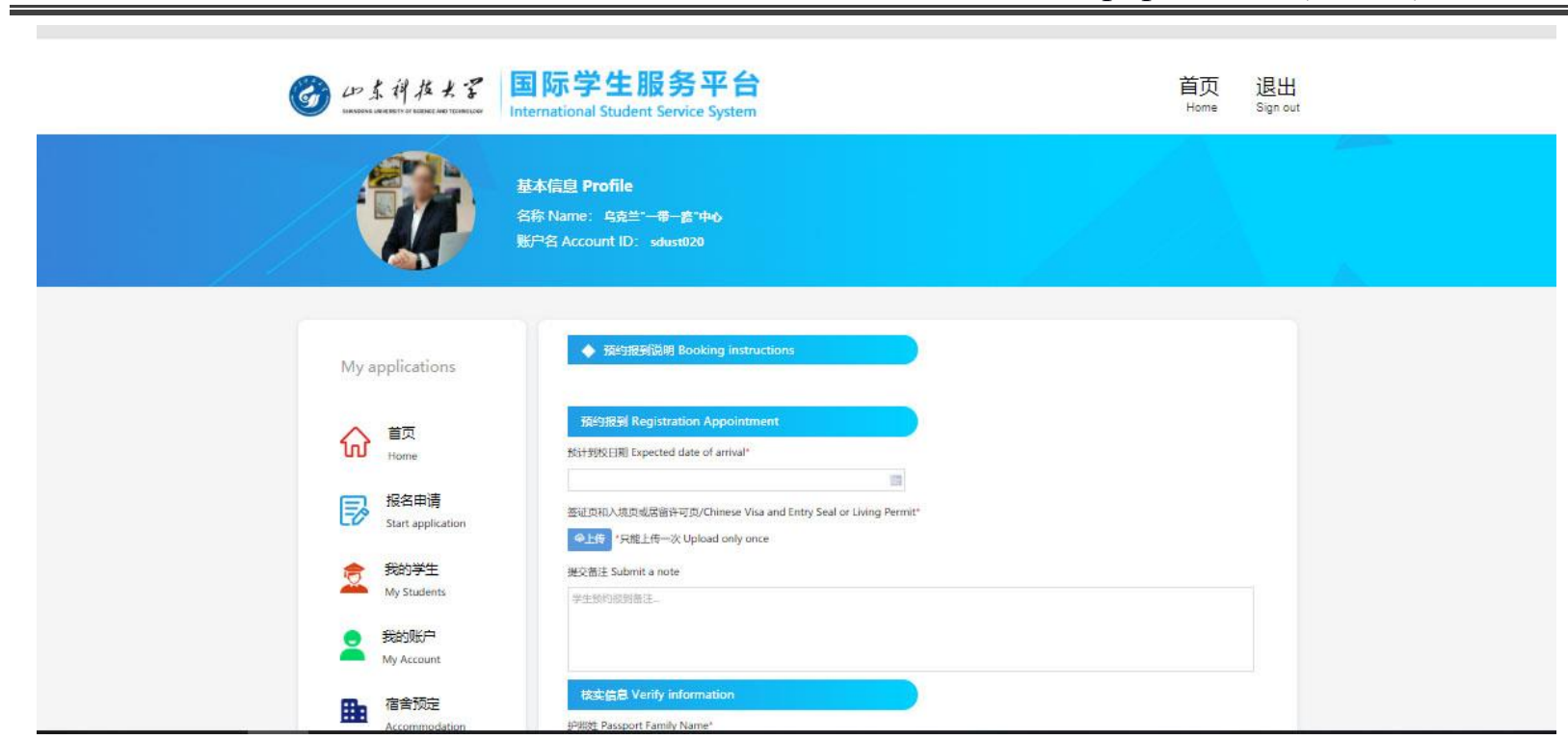

Рисунок 8 - Скріншот форми зворотного зв'язку міжнародної системи сервісу для студентів

Незважаючи на те, що ця система і спрямована на полегшення зарахування та подальшого навчання студентів, іiі функціональні можливості обмежені. Спостерігається поодинока інтеграція закладами вищої освіти цієї системи із внутрішніми сервісами управління людськими ресурсами, проте глобального розвитку вона ще не досягла.

Для глобалізації процесу навчання іноземних студентів доцільно використовувати інтегровану навчальну платформу. Для такої платформи розроблено ряд навчальних курсів. Курс Master of Business Administration прийнято для ведення спільної українсько-китайської програми підготовки фахівців (рис. 9 - 11).

На думку автора гармонізація китайської міжнародної системи сервісу для студентів та інтегрованої навчальної платформи дасть можливість підвищити рівень управління людськими ресурсами для закладів навчання.

\section{Висновки}

Для глобалізації процесу навчання іноземних студентів доцільно використовувати інтегровану навчальну платформу. Для цієї платформи розроблено ряд навчальних курсів. Курс Master of Business Administration прийнято для ведення спільної українсько-китайської програми підготовки фахівців.

Гармонізація китайської міжнародної системи сервісу для студентів та інтегрованої навчальної платформи дасть можливість підвищити рівень управління людськими ресурсами для закладів навчання.

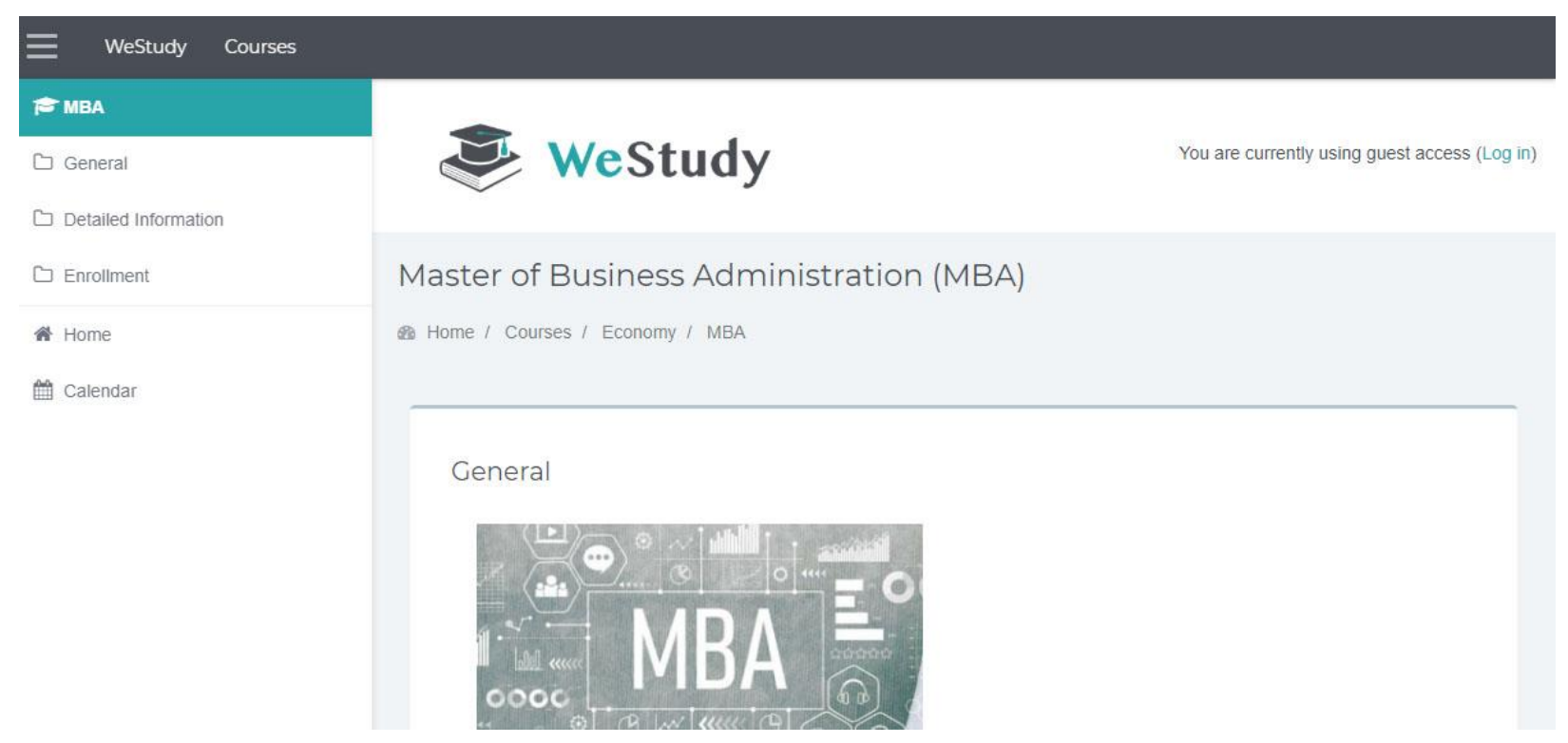

Рисунок 9 - Скріншот головної сторінки інтегрованої навчальної платформи 


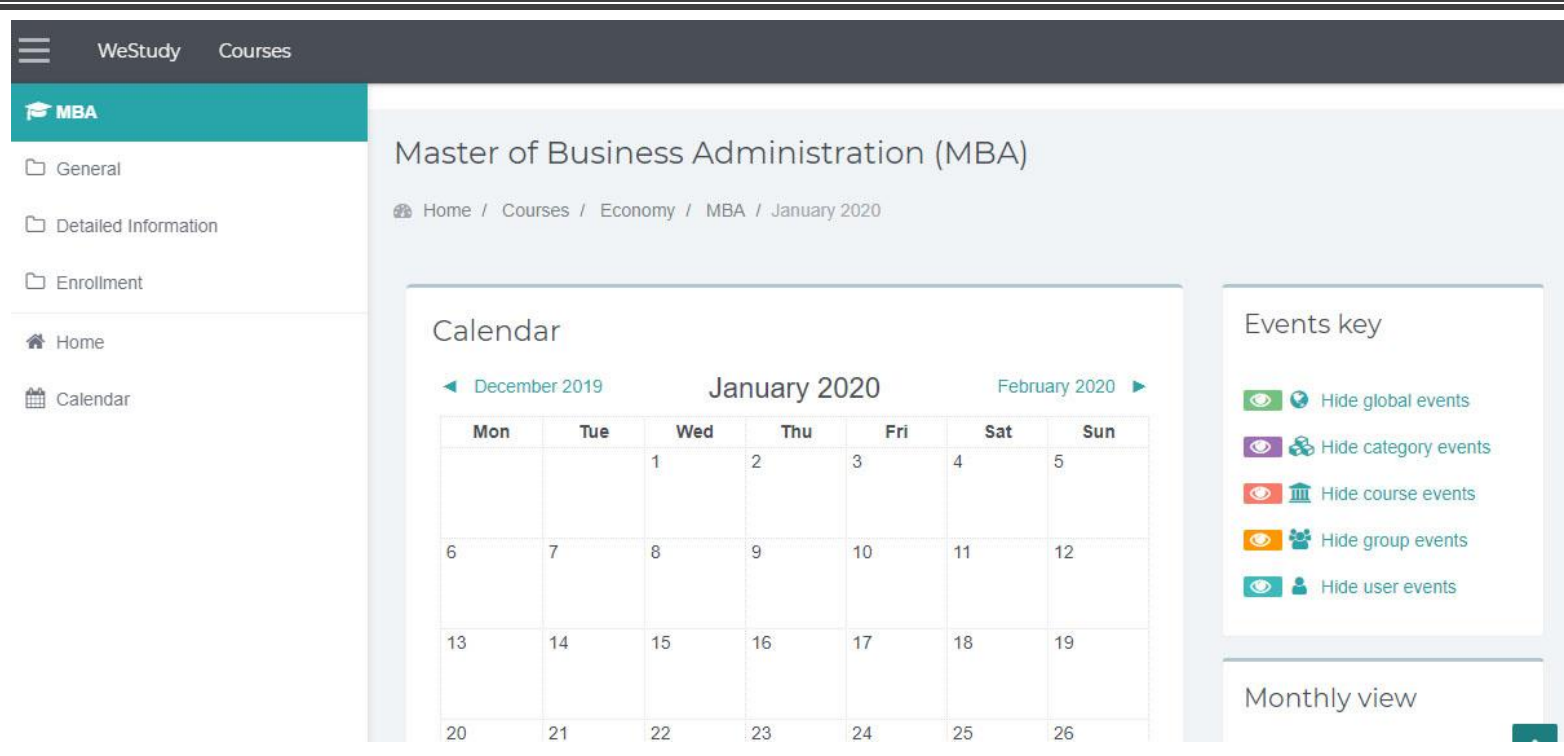

Рисунок 10 - Скріншот календарю інтегрованої навчальної платформи

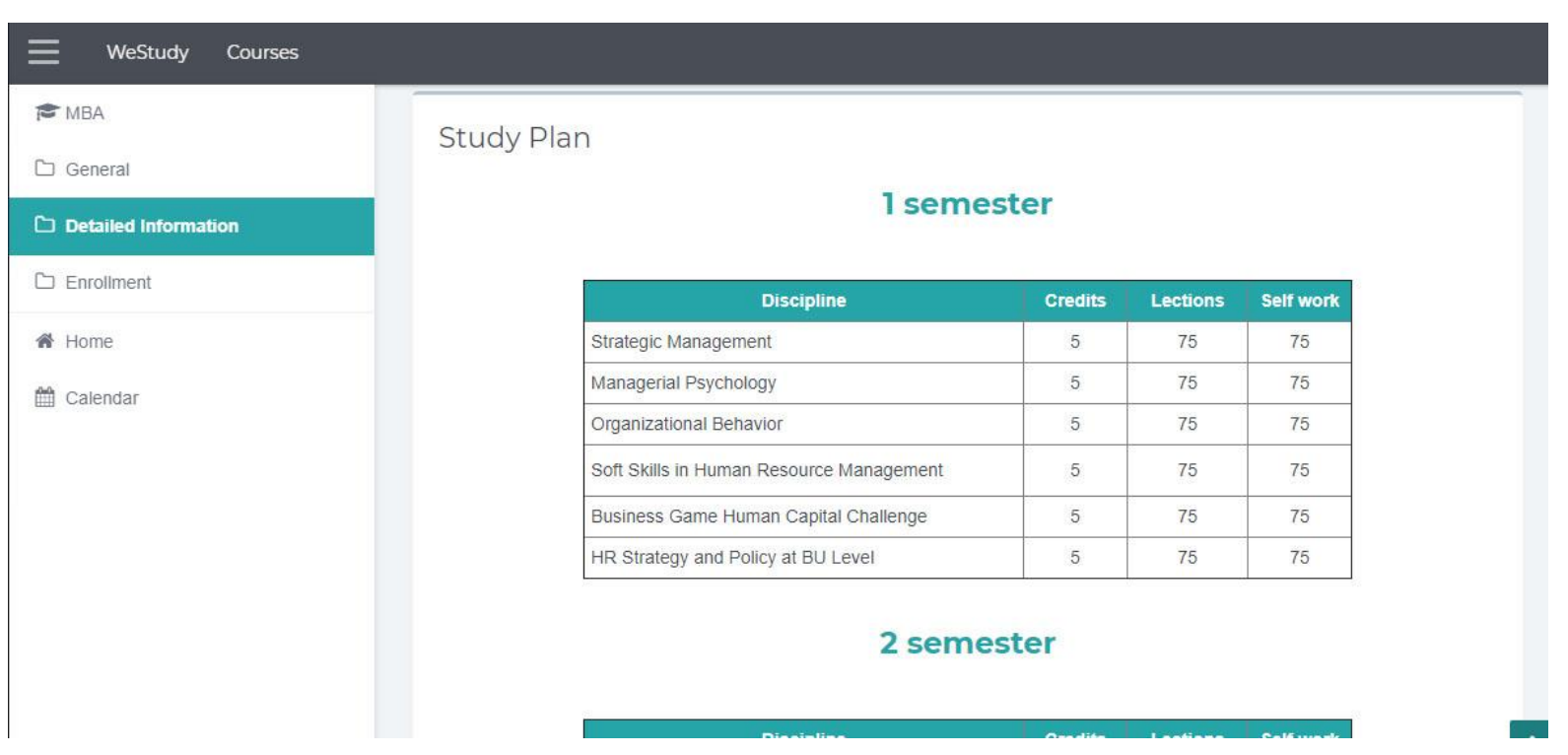

Рисунок 11 - Скріншот навчального плану інтегрованої навчальної платформи

\section{References}

1. Agarwal, R. \& Ferratt, T.W. (1999). Crafting an HR strategy to meet the need for IT workers. Communications of the ACM, 44(7), 58-64.

2. Lengnick-Hall, M.L. \& Moritz, S. (2003). The Impact of E-HR on the Human Resource Management Function. Journal of Labor Research, 24(3), 365 - 379.

3. Hustad, E. \& Munkvold, B.E. (2005). IT-supported competence management: A case study at Ericsson. Information Systems Management, Spring, $78-88$.

4. Hempel, P.S. (2004). Preparing the HR profession for technology and information work. Human Resource Management, $2-3,163-177$.

5. Buckley, P, Minette, K., Joy, D, Michaels, J. (2004). The use of an automated employment recruiting and screening system for temporary professional employees: A case study. Human Resource Management, 2-3, 233 - 241.

6. Snell, S.A., Stueber, D. \& Lepak, D.P. (2002). Virtual HR Departments: Getting out of the middle. In R. L. Heneman and D. B. Greenberger (Eds.). Human resource management in virtual organizations, 81-101, CT: Information Age Publishing.

7. Kovach, K.A. \& Cathcart, C.E. (1999). Human Resource Information System (HRIS): Providing business with rapid data access, information exchange, and strategic advantage. Public Personnel Management, 28(2), 275 - 282.

8. Lepak, D.P. \& Snell, S.A. (1998). Virtual HR: Strategic human resource management in the 21st century. Human Resource Management Review, 8 (3), 215 - 234.

9. Ball, K.S. (2001). The use of human resource systems: a survey. Personnel Review, 30(6), 677 - 93. 
10. Othman, R. \& Teh, C. (2003). On developing the informated workplace: HRM issues in Malaysia. Human Resource Management Review, 13 (3), 393 - 406.

11. Bergenhenegouwen, G.J., ten Horn, H.F.K. \& Mooijman, E.A.M. (1996). Competence Development - A Challenge for HRM professionals: Core competencies of organizations as guidelines for the development of employees. Journal of European Industrial Training, 20(9), $29-35$.

12. Niederman, F. (1999). Global information systems and human resource management: A research agenda. Journal of Global Information Management, 7(2), 33 - 39.

13. Pickett, L. (1998). Competencies and managerial effectiveness: Putting competencies to work. Public Personnel Management, 27(1), $103-115$.

14. Ashbaugh, S. \& Miranda, R. (2002). Technology for Human Resource Management: Seven questions and answers. Public Personnel Management, 31(1), $7-20$.

15. Shrivatsava, S. \& Shaw, J.B. (2003). Liberating HR through technology. Human Resource Management, 42, 3, $201-222$.

16. Pinsonneault, A. \& Kraemer, K. (1993). The impact of information technology on middle managers. MIS Quarterly, September, $271-292$.

17. Berardine, T. (1997). Human resource information systems improve management decision-making. Canadian Manager, $22(4), 17-18$.

18. Totty, P. (2001). Human resources information systems. Credit Union Magazine, 67(8), 53 - 55.

19. Caudron, C. (2003). Counting heads and hiring, firing and managing them too. PROFIT Oracle's e-business magazine, February, $79-80$.

20. Dave Foxall Five social HRMS tools to streamline collaborative projects https://www.hrmsworld.com/social-hrms-toolsfor-collaboration.html

21. High Line Review https://www.betterbuys.com/hrms/reviews/high-line/

22. Kronos Workforce Ready Review https://www.betterbuys.com/hrms/reviews/kronos-workforce-ready/

23. Zhou, Huan. (2019). Tendention of IT application in human resurces management on the example of Chinese higher education facilities. Management of development of complex systems, 38, 125 - 132.

Стаття надійшла до редколегії 18.02.2020

\section{Zhou Huan}

$\mathrm{PhD}$ student Department of Information Systems and Technology, orcid.org/0000-0003-1187-8161

Taras Shevchenko National University of Kyiv, Kyiv

\section{HARMONIZATION OF CHINESE INTERNATIONAL STUDENT SERVICE SYSTEM}

Annotation. Modern software facilitates the management of human resources in small, medium and large enterprises of technical, information, financial and other areas. However, the issue of integrated software for educational institutions remains open. The development of China's international student service system has been steady, however, according to the author, is not rapid enough. It is advisable to use an integrated learning platform to globalize the learning process for international students. A number of training courses have been developed for this platform. Harmonization of China's international student service system and integrated learning platform will enhance the human resources management of educational institutions. platform

Keywords: harmonization of educational platforms; international system of service for students; integrated educational

\section{Link to publication}

APA Zhou, Huan, (2020). Harmonization of Chinese International Student Service System. Management of Development of Complex Systems, 41, 147 - 155, dx.doi.org \10.32347/2412-9933.2020.41.147-155.

дСТУ Чжоу Хуань. Гармонізація китайської міжнародної системи сервісу для студентів [Текст] / Чжсу Хуань // Управління розвитком складних систем. - 2020. - № 41. - C. 147 - 155, dx.doi.org\10.32347/24129933.2020.41.147-155. 